\title{
HowCompany Manage Stakeholder Engagement For Sustainable Tourism Development In Indonesia?
}

\author{
Gayatri Atmadi ${ }^{*}$ \\ ${ }^{1}$ Department of Communication Science, Universitas Al-Azhar, Jakarta Selatan, \\ Indonesia \\ Jalan Sisingamangaraja No.2 Jakarta Selatan, Indonesia \\ Email: gayatri@uai.ac.id
}

\begin{abstract}
The background of this research is that in the past, the increasing trend of mountain climbing in Indonesia has reportedly raised environmental problems, especially regarding the tremendous volume of rubbish left behind mountain climbers. Plastic waste threatens the Indonesia tourism industry in mountain areas. The government stated that the continuously increasing plastic waste threatens to ruin Indonesia's tourism sector. The mineral water industry is one of the government's primary focuses in its plastic waste reduction. As Indonesia's largest plastic-bottled mineral water brand, Aqua is pledging to remove more plastic from the environment than it uses by 2025. The purpose of the research is to get a descriptive analysis of how the company can manage its stakeholder engagement for reducing plastic waste in Indonesia. This research employed a qualitative narrative analysis method with a case study around Aqua's efforts for reducing plastic waste in Indonesia and data collected from digital media. The principal results of the research show that Aqua made good collaboration between the Trashbag Community Indonesia, The Ministry of Environment and Forestry, and media journalists on the program "Sapujagad 2017" by removing 5 tons of rubbish from Indonesia's mountains. In conclusion, a successful company must do stakeholder engagement and corporate social responsibility activities for supporting sustainable tourism development in Indonesia.
\end{abstract}

Keywords: corporatesocialresponsibility, public relations, stakeholderengagement, sustainable tourism development 


\begin{abstract}
Abstrak
Latar belakang penelitian ini adalah bahwa di masa lalu, tren peningkatan pendakian gunung di Indonesia dilaporkan telah menimbulkan masalah lingkungan, terutama mengenai volume sampah yang sangat besar yang tertinggal di belakang para pendaki gunung. Sampah plastik mengancam industri pariwisata Indonesia di daerah pegunungan. Pemerintah menyatakan bahwa sampah plastik yang terus meningkat mengancam untuk menghancurkan sektor pariwisata Indonesia. Industri air mineral adalah salah satu fokus utama pemerintah dalam pengurangan limbah plastiknya. Sebagai merek air mineral botol plastik terbesar di Indonesia, Aqua berjanji untuk menghapus lebih banyak plastik dari lingkungan daripada yang digunakan pada tahun 2025. Tujuan dari penelitian ini adalah untuk mendapatkan analisis deskriptif tentang bagaimana perusahaan dapat mengelola keterlibatan pemangku kepentingannya untuk mengurangi limbah plastik di Indonesia. Penelitian ini menggunakan metode analisis naratif kualitatif dengan studi kasus seputar upaya Aqua untuk mengurangi limbah plastik di Indonesia dan data yang dikumpulkan dari media digital. Hasil utama dari penelitian ini menunjukkan bahwa Aqua membuat kolaborasi yang baik antara Komunitas Trashbag Indonesia, Kementerian Lingkungan Hidup dan Kehutanan, dan jurnalis media pada program "Sapu jagad 2017" dengan menghilangkan 5 ton sampah dari pegunungan Indonesia. Perusahaan yang sukses harus melakukan pelibatan terhadap pemangku kepentingan dan CSR (corporate social responsibility) perusahaan untuk mendukung pengembangan pariwisata berkelanjutan di Indonesia.
\end{abstract}

Kata kunci: tanggung jawab sosial perusahaan, hubungan masyarakat, keterlibatan pemangku kepentingan, pengembangan pariwisata berkelanjutan 


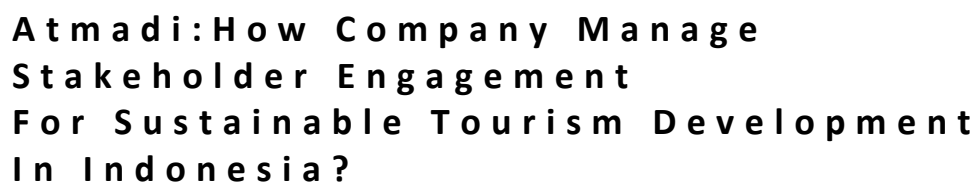

\section{INTRODUCTION}

Generally speaking, for the past several years, plastic waste threatens theIndonesia tourism industry in the beach, sea and mountain areas. The government of Indonesia has several times sought to foster relationships with the private sector to be involved in efforts to reduce the plastic waste discharged from their company's products. A previous study about the tourism industry conducted by Maryam Ziaabadi explained that tourist destinations that have water and air pollution can not retain control over the tourists' health (Ziaabadi et al. 2017). For this reason, they can not attract tourists and will be far away from sustainable development aims.

According to Rhett A. Butler, "Indonesia is an archipelago of more than 10,000 islands, Indonesia has a wide array of terrestrial and marine ecosystems, including parts of the world's third-largest rainforest and the famed Coral Triangle (Butler, 2016). "The biodiversity of flora, fauna, ecosystems, and cultural diversity are the promising attractions for tourism development in Indonesia. Regina Butarbutar and Soemarno said, " Ecotourism and nature-tourism are suitable to improve the tourism standing, based on their nature and heritage tourism, the local social capital, and its tourism carrying capacity." (Butarbutar, 2013).

Previous studies from SoheilaKhoshnevisYazdi indicated that ecotourism can be a very useful means for promoting the socio-economic development of host communities while generating resources for the preservation of ecosystem and cultural assets (Yazdi, 2012). In this condition, ecologically weak and uncertain areas can be protected with the financial returns of ecotourism activities made by both the private and public sectors. Furthermore, the research initiated by TutiHerawati, et al reported that local stakeholders always have interests and positions in each of the programs that they make. This has an impact on the decisions that take. Policymakers at the central level must consider their aspirations to be able to realize the success of the program. Stakeholders have a relationship to establish cooperation and complement each other so that there is potential for conflicts to occur. To optimize the role in determining human 
resource management and development policies in the Ministry of Environment and Forestry, understanding is needed.

Nature tourism activities become increasingly popular as enjoyable and attractive tourism activities in the form of camping grounds, riding a bicycle, hiking, rock climbing, and rafting. However, we must realize that tourism is one of the main sources of pollution in Indonesia. SoheilaKhoshnevisYazdi emphasized that tourism development can have both positive and negative impacts on destinations. Sustainable tourism development attempts to find a balance between these impacts to create an improved quality of life for the host community and the destination. What's the meaning of sustainable tourism development?

World Tourism Organization on United Nations Environment Programme(United Nations Environment Programme., 2008)explained, "Sustainable tourism development meets the needs of present tourists and host regions while protecting and enhancing the opportunity for the future. It is envisaged as leading to management of all resources in such a way that economic, social, and aesthetic needs can be fulfilled while maintaining cultural integrity, essential ecological processes, biological diversity, and life support system."

Previous research conducted by Muhammad AsadSaleem Malik, Syed Asim Shah, and Khalid Zaman about "Tourism in Austria : Biodiversity, Environmental Sustainability, and Growth" Issues indicated that ecological, social, and environmental sustainability are the three main pillars of environmental sustainability that required proper attention and care for building sustainable tourism agenda in constraint environment (Zaman, 2016). Assurance of environmental sustainability attracts international tourists' to spend their leisure time in healthy and wealthy pleasure destinations.

The ministry's waste management director-general, Rosa Vivien Ratnawati told to Kahfi, The Jakarta Post journalist, " We want to urge (businesses) to shift their paradigm in manufacturing their products, such as by using more environmentally friendly materials, as part of our efforts to cut down on waste production in the upstream." Rosa said that the ministry's road map would cover three industries: food and beverage manufacturing; food and beverage services, and retail.” (Kahfi, 2019). 


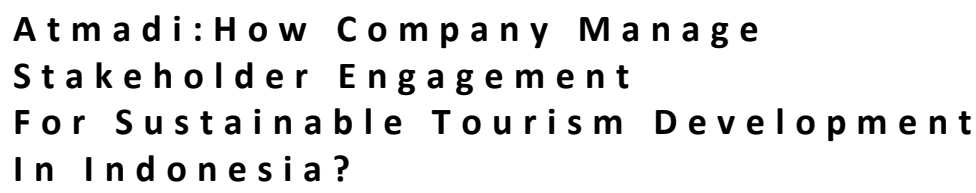

As beverage manufacturing, Aqua founded in 1973 as the pioneer of bottled drinking water in Indonesia, which then established a strategic partnership with Danone in 1998. To help reduce Earth's waste, Aqua makes use of recycled materials to use for cardboard packaging, allowing its plants to generate less cardboard waste. As a company that has a mission to bring health and goodness to people, Aqua will always maintain stability between business sustainability with nature preservation for healthier Indonesia. Aqua also creates a new life cycle for the entire plastic packaging existing in the market, optimizes the responsible collection of waste, and works towards $100 \%$ recyclable packaging.

To reduce negative impacts and maximize profits to the environment, PT. TirtaInvestama, the producer of Danone Aqua bottled mineral water, develops and manages good stakeholder relations both internal and external in all places in Indonesia. Who are stakeholders of Aqua? Freeman on Joep Cornelissen's book explained, " A stakeholder is any group or individual who can affect or is affected by the achievement of the organization's purpose and objectives ".indirectly achieve the objectives will be influenced by stakeholders. The active role can be shown in the implementation of the main tasks, authorities, and functions of the stakeholders. Stakeholders have the possibility to perform role dysfunction. Negative impacts will arise if stakeholders do not play their roles properly.

There are some kinds of Aqua stakeholders such as customers, employees, distributors, suppliers, shareholders, government, media, and local communities. (Cornelissen, 2009). Aqua strengthens double commitments for sustainable benefits that are manifested by renewing the focus and target of Aqua Lestari that will be achieved in 2020. There are four main pillars in Aqua Lestari : (1). The Protection of water resources ; (2). Packaging optimization and packaging waste collection ; (3). Sustainable product distribution ; (4). Reduction of carbon emissions. Those four pillars are supported by the pillar of community and community involvement because Aqua realizes that to make each initiative real requires the support of all stakeholders that the results achieved are right on target and guaranteed sustainability.

In the past few years, the increasing trend of mountain climbing in Indonesia has reportedly raised environmental problems, especially regarding the 
very big volume of rubbish left behind mountain climbers. Plastic waste threatens the Indonesia tourism industry in mountains and forest areas. The government stated that the continuously increasing plastic waste threatens to ruin Indonesia's tourism sector. As Indonesia's largest plastic-bottled mineral water brand, Aqua handled corporate communication and corporate social responsibility program by participating in Sapujagad 2017 campaign.

Sapujagad is a special event held every two years to collect all kinds of rubbish that is scattered in mountainous areas and forests throughout Indonesia. The news about Sapujagad 2017 already published on several digital media in Indonesia, such as kompas.com; mediaindonesia.com; the jakartapost.com; kontan.co.id; rri.co.id; tempo.co., and others. This research aims to implement narrative analysis in news texts of digital media: kompas.com. All media texts have narratives, whether they are printed media, broadcast media or digital media.

The difference between this research and previous research is that this research focuses more on analysis related to the clean environment activities of the "2017 broom universe" held by Aqua and then covered on digital media: kompas.com.while, Soheila research focus on ecotourism activities can be a means to promote the socio-economic development of the community. While, the research of Muhammad Asad Saleem Malik, et al explains that there are 3 main pillars in environmental sustainability that require proper attention and care. This study aims to provide a comprehensive review of collaboration between Aqua and its stakeholders in handling the "SapuJagad 2017“" campaign. Second, get an understanding of narrative analysis on the article of news about how Aqua can manage stakeholder engagement for sustainable tourism development in Indonesia.

\section{METHODS}

This research employed a qualitative narrative analysis method with a case study about Aqua's effort for reducing plastic waste in Indonesia that already published as news texts in digital media as a narrative. Anna De Fina and Barbara Johnstone explained (2015:158), “ narrative is embedded in social activity both on the level of interaction and on the level of discursive and social practice. Stories arise in the context of repeatable activities such as chat, courtship, and the socialization of newcomers, among many other things, and narrative serves 


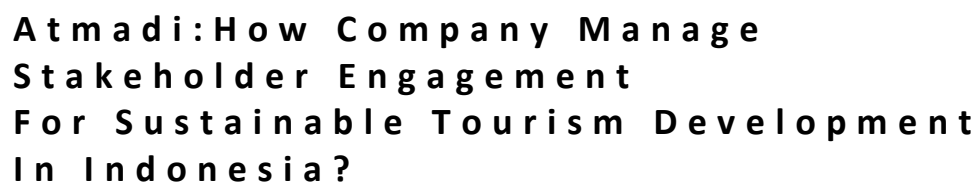

different functions in different sociocultural settings."

Unit analysis of this research is a news article and some photos from Kompas.com with the title The Impact of The Mountain Climbing Trend, The Volume of Garbage on The Mountains Has Increased by Wahyu Aditya Prodjo, August 18, 2017, 09:36 WIB.

\section{RESULT AND DISCUSSION}

A Brief of Aqua. Aqua is a famous brand of bottled drinking water in Indonesia produced by PT. Aqua Golden Mississippi since 1973. Besides Indonesia, Aqua is also sold in Brunei, Malaysia, and Singapore. In 1998, Aqua Group made strategic cooperation with Danone and applies Danone values, namely Humanity, Openness, Closeness, and Enthusiasm. As their commitment to managing the company operations responsibly, Aqua and Danone have a dual commitment that businesses must have a social contribution by building partnerships with their stakeholders.

Since June 5, 2018, Aqua and Danone have implemented their commitment to becoming a pioneer in solving the problem of plastic waste in Indonesia through three important commitments, namely innovation, education, and plastic bottle collection. With the spirit of collaboration with their stakeholders, Aqua and Danone participated in social campaign Sapu jagad 2017 for saving ecotourism in Indonesia.

Sapta Nirwandar said, " Ecotourism in Indonesia defined as activities of responsible traveling in intact areas or in areas which are named according to the role of nature. The purpose of such activities is: being to enjoy natural beauty, involving education, understanding, and supports conservation, as well as increasing the income of the local communities ". There are 50 national parks in Indonesia ranging from sea, rivers, endemic species, rain forests, and mountains. Some of the popular national parks in Java are Halimun Mount, Gede Pangrango Mount, Bromo Tengger Semeru, Mount Merapi, Mount Merbabu, and Mount Ciremai.

For reducing the impact of plastic waste in the mountains area, Aqua participated in the Sapu jagad 2017 campaign by handling stakeholder 
management. Brugha and Varvasovszky, (Brugha, 2019)brand Wolfe and Putler (Wolfe, 2002) explained that the purpose of stakeholder management is to form, monitor, and maintain constructive relationships with the organization's stakeholders, i.e. to understand their relative importance, to identify new or upcoming stakeholders, and to decide which strategies are important in building relationships with important stakeholders.

For conducting stakeholder management well, there are some principles of stakeholder management that the company should implement. According to Andrew L. Friedman and Samantha Miles, one of some principles is managers should work cooperatively with other entities, both public and private, to ensure that risks and harms arising from corporate activities are minimized and, where they cannot be avoided, appropriately compensated. This principle means that the company should work cooperatively with government institutions, local communities, employees, and media journalists to ensure that risks and harms arising from Aqua products are minimized (Miles, 2006).

Sapu jagad campaign was a good collaboration program that Aqua already participated in August 2017. Sapu jagad is a biannual event to collect trash on 17 mountains and forest areas across Indonesia. Based onSapu jagad 2015 data, around 2.4 tons or 600 bags of garbage were gathered from 15 mountains in Indonesia, consisting of 769 kilograms of plastic waste, $491 \mathrm{~kg}$ of plastic bottles and $213 \mathrm{~kg}$ of discarded cigaret butts, reported by kompas.com on thejakartapost.com, August 21, 2017. Before executing the Sapu jagad 2017 campaign, Aqua handled corporate communication activities with its stakeholders, such as employee relations, media relations, government relations, and community relations. Joep Cornelissen said, "corporate communication is a management function that offers a framework for the effective coordination of all internal and external communication with the overall purpose of establishing and maintaining favorable reputations with stakeholder groups upon which the organization is dependent" (Cornelissen, 2009).

In nowadays' workplace, people come to work not just for earning an income or to do their job. They are coming into work for a special purpose that gives usefulness for their life. In Aqua company that pledges to remove more plastic from the Indonesian environment, 111 employees participated in Sapu jagad 2017 campaign as Aqua Volunteer Club. They took plastic waste from 


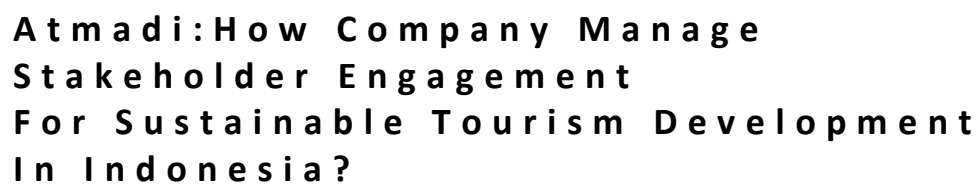

tourist destinations, such as Penanggungan mountain, Salak mountain and Batur mountain to Garbage Bank and Recycling Business Unit of Aqua Group. In other words, Aqua already supported sustainable tourism development in some mountains area in Indonesia as tourist destinations.

Sapu jagad 2017 campaign supported by The Ministry of Environment and Forestry, Trashbag Community Indonesia, Aqua employees, and media journalists. Trashbag Community is a nature lover group that was formed on November 11, 2011, at Taman Nasional Gunung Gede Pangrango. The community has slogan " Gunung Bukan Tempat Sampah " and works together cleaning mountains in Indonesia. Headquartered at Kalibata Timur area in South Jakarta, Trashbag Community also educates climbers and students about how important to keep mountains clean as tourist destinations in Indonesia.

Many journalists already published a good report about Sapu jagad 2017 campaign to their public, such as kompas.com, tempo.com, thejakartapost.com, suara.com, m.rri.co.id, mix.co.id, kumparan.com, and mediaindonesia.com. Those good publications can make a good reputation for Aqua as the best quality of mineral water in Indonesia that very care about environmental problems. Based on the adaptation of the stakeholder model of strategic management by Joep Cornelissen, Aqua already made good collaboration with its stakeholders in the handling program " Sapu jagad 2017 ". Figure 1 explains that Aqua did two-way communication with the Ministry of Environment \& Forestry, Trashbag community, media journalist, and its employees so the company can perform its activity as corporate social responsibility in the mountains area as part of tourist destinations in Indonesia. Moreover, Aqua supported protecting nature reserves and forests from plastic waste. Furthermore, the company can maintain a good image and a good reputation in society and support sustainable tourism development in Indonesia. 
Figure 1

Aqua Stakeholder Engagement Model

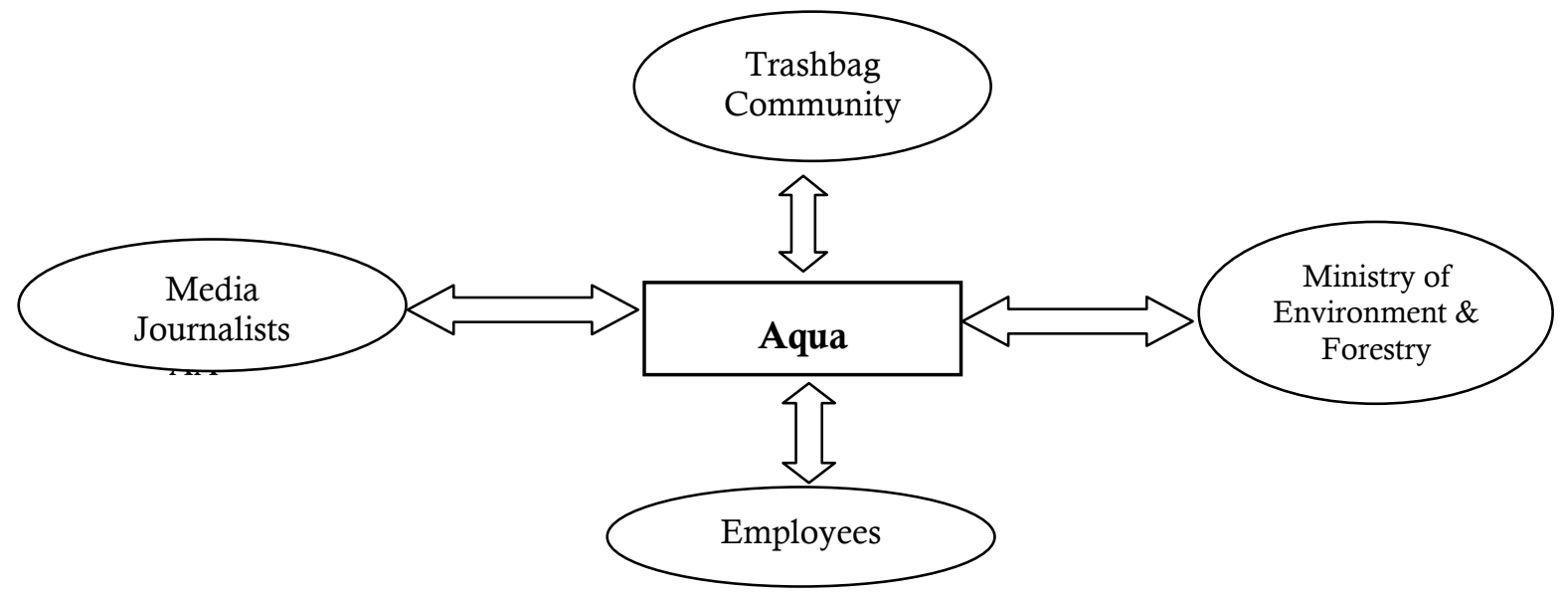

Source from the stakeholder model of strategic management by Joep Cornelissen

Polonsky \& Speed said that corporate social responsibility involves broadly in environmental problems, social welfare, education, and global warming and could be classified into sponsorship, cause-related marketing, and corporate philanthropy (Polonsky, 2001). In regard to public relations in the society of the company, McWilliams, Siegel \& Wright (McWilliams, A., D. S. Siegel, 2006) and Lai et al. (Lai, C.S., C. J. Chiu, C. F. Yang, 2010) emphasized that corporate social responsibility is an idea of sustainable development, involving in various levels in the society, from environmental problems to social welfare, education, and global warming. Another definition of corporate social responsibility explained by Lynda Bourne, as the responsibility of an organization towards stakeholders (individuals or groups) who may be overlooked or unfairly treated in the shareholder value model of organizational management (Bourne, 2009).

In Aqua's case, the company took responsibility to remove more plastic from the Indonesian environment and educate consumers to be more creative in collecting and recycling their plastic waste into something of better value. Those engaging stakeholders is an essential part of public relation strategy for maintaining a good image in society. James Noland and Robert Phillips emphasized that engaging stakeholders is a necessary part of the strategy because for a firm to determine its strategy without having first engaged its stakeholders would be literally, to disengage its mission and vision from its identity(Noland, and Robert, 2010). 


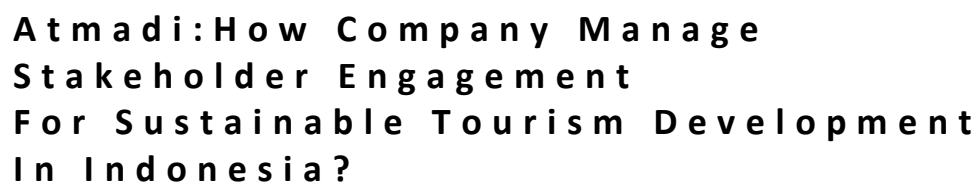

With qualitative narrative analysis method, this research wants to analyze article of news with the title "Imbas Tren Pendakian Gunung, Volume Sampah di Gunung Meningkat “ or " The Impact of The Mountain Climbing Trend, The Volume of Garbage on The Mountains Has Increased “ by Wahyu Aditya Prodjo on kompas.com.as seen on Figure 2.Four photos are used for supporting the news about Trashbag Community activities on Sapu Jagad 2017. Based on Eriyanto's explanation about narrative structure, indicates that in general, the news about " The Impact of The Mountain Climbing Trend, The Volume of Garbage on The Mountains Has Increased " consists of four structures : (1). Disruption, (2). Awareness of disruption, (3).Disruption solving, (4).Equilibrium (Eriyanto, 2013).

Figure 3

Structure Narrative of News Article from Kompas.com

Narrative Structure :

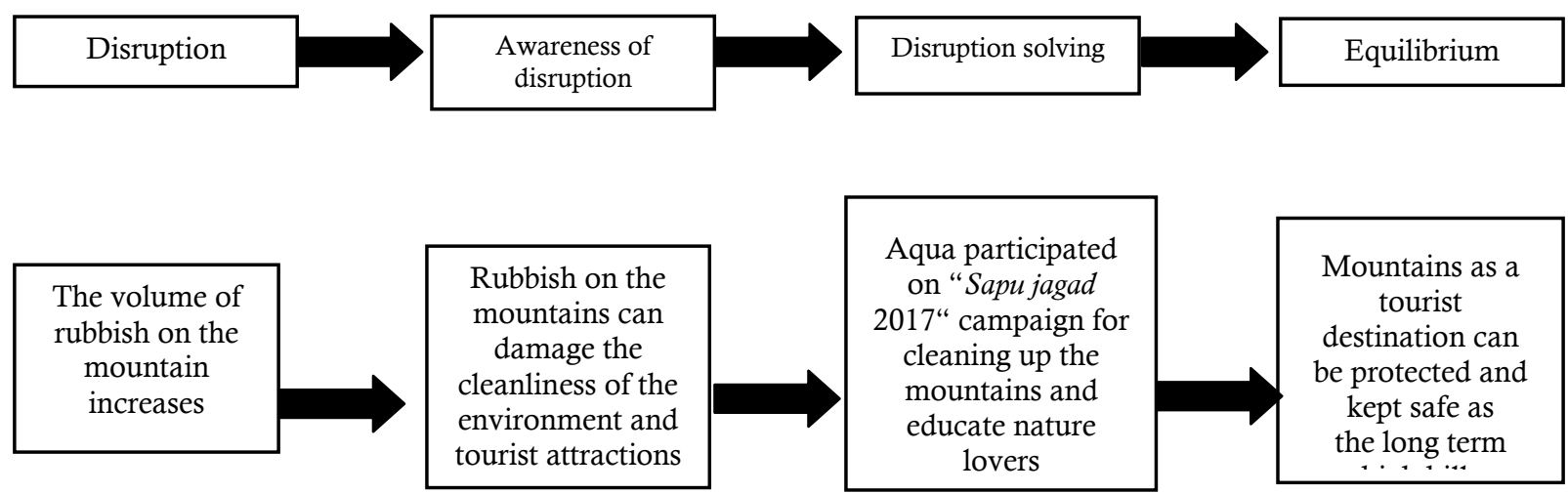

First of all, the news headline The Impact of The Mountain Climbing Trend, The Volume of Garbage on The Mountains Has Increased describes the fact that the problem of garbage in the mountains needs serious attention because more people have a hobby of climbing mountains as one of the natural tourist destinations in Indonesia. As a healthy hobby for body and soul, mountain climbers as nature lovers need to be educated to always maintain cleanliness wherever they are. The local government needs to take decisive action in the form of the threat of fines of hundreds of thousands of rupiah for mountain climbers 
who allow food and drink leftovers to be wasted in a tourist area, making the mountain environment dirty.

The first photo as seen in Figure 4. below the news headline explains that some mountain climbers brought a big plastic bag for collecting garbage in the mountains area. They were some members of the Trashbag Community who cleaned up the environment of Mount Rinjani from piles of garbage scattered everywhere.

Then, the news lead on the first paragraph emphasized that the trend of mountain climbing made the volume of garbage on the mountains had increased. If we don't care about garbage in the mountain so it can damage the cleanliness of the environment and reduce the number of tourist arrivals to the mountains so that it can reduce the income of local people and damage the image of Indonesian tourism.

Figure 4

Some Mountain Climbers Brought Big Plastic Bag for Collecting Garbage

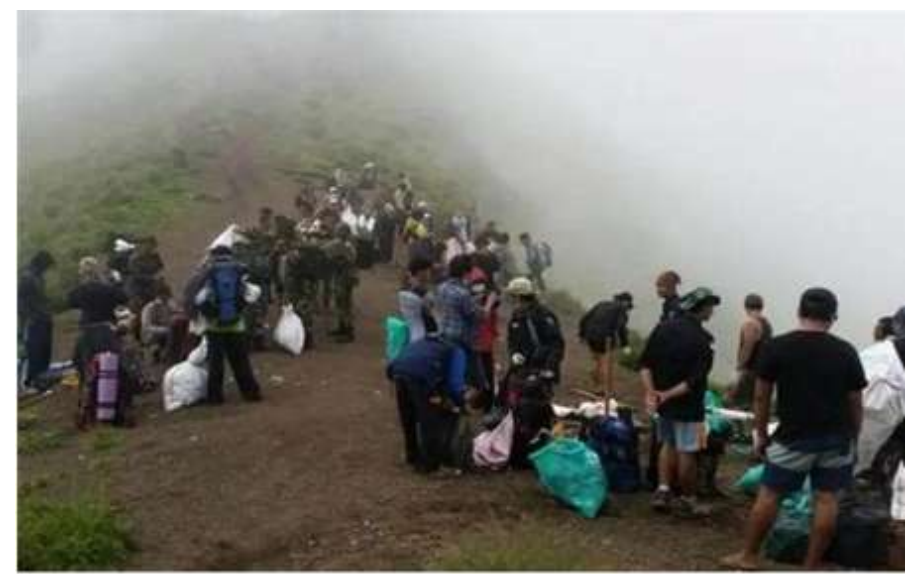

In the second paragraph, kompas.com indicates Trashbag Community already had a record of environmental problems on mountains area in Indonesia. Trashbag Community is a community for nature lovers who very care about the cleanliness of the environment in the mountains, forests, beaches, and the sea as tourist attractions in Indonesia. The community has a slogan: Keep Our Mountain Green and Clean.

The next paragraphs as seen in Figure 5. (3th paragraph until 5th paragraph) explain that the big volume of trash on the mountain can change the behavior and patterns of animal life. The record of Sapu Jagad 2015 as Trashbag 


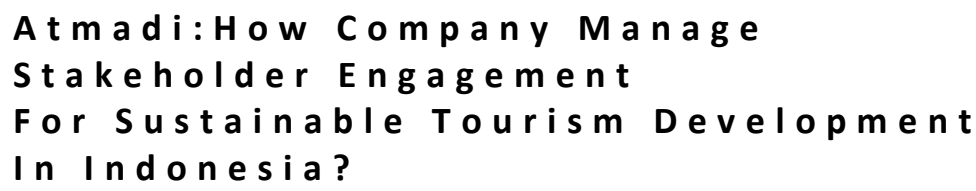

Community's campaign already removed 2,4-ton garbage from 15 mountains area in Indonesia. Plastic garbage dominated with $36 \%$ or about 769 kilograms, plastic bottle garbage $23 \%$ or about 491 kilograms, and cigarette butt trash $10 \%$ or about 213 kilograms.

The sixth paragraph explains that the high volume of waste is also recorded on Mount Rinjani. Agus Budi Santosa, the Head of the Gunung Rinjani National Park Headquarters, reported last year, 1.5 tons of garbage were successfully transported from Mount Rinjani, West Nusa Tenggara (NTB). Then, the second photo as seen in Figure 6 describes the atmosphere in the Ministry of Environment and Forestry (LHK) office where Trashbag Community got support from them to handle the Sapu Jagad 2017 campaign. The members of the Trashbag Community looked so excited and happy for preparing the next campaign program.

Figure 5

The Ministry of Environment and Forestry supported Sapu jagad 2017 campaign Program

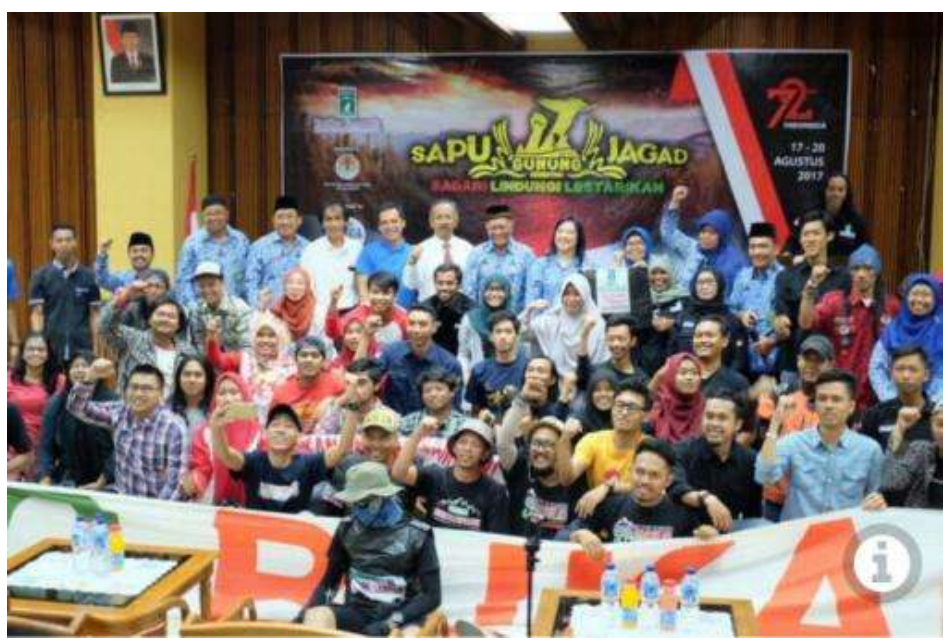

In the $7^{\text {th }}$ and $8^{\text {th }}$ paragraphs,Agus Budi Santosoexplains about Clean Up activity at Gunung Rinjani National Park on December 10-11, 2016 already removed garbage 1,474.2 kilograms. Agus also tells that the amount of waste weighing almost 1,5 ton consists of $413 \mathrm{~kg}$. organic waste and 1,061.2 kg. nonorganic waste which consists of mostly plastic waste such as plastic drinking bottles, straws, food wrappers, and plastic bags. 
In the 9th paragraph, The Minister of Environment and Forestry, Siti Nurbaya said that awareness of mountain climbers is needed to preserve the environment, especially regarding the problem of garbage in the mountains.

Paragraph 10th explains that the volume of mountain trash will continue to increase if the climbers are not aware of their responsibility for environmental preservation. In a press release that received by Kompas Travel (17/8/2017), The Minister of Environment and Forestry, Siti Nurbaya also said that all of us have to be responsible for protecting the environment, not only the government and Trashbag Community. It means that all people in Indonesia must be able to maintain the cleanliness of the environment wherever located without exception.

On 11th paragraph shows that Trashbag Community was supported by The Minister of Environment and Forestry for the Sapu Jagad 2017 campaign on August 15-24, 2017 with 1.346 participants consisting of students from nature communities and the public.

Afterward, the third photo as seen in Figure 7 describes three young men as part of the Trashbag Community removed bottle plastic waste in the mountains area. They work voluntarily to maintain the cleanliness of the mountain as a tourist destination for nature lovers.

Figure 6

Trashbag Community members collected plastic waste

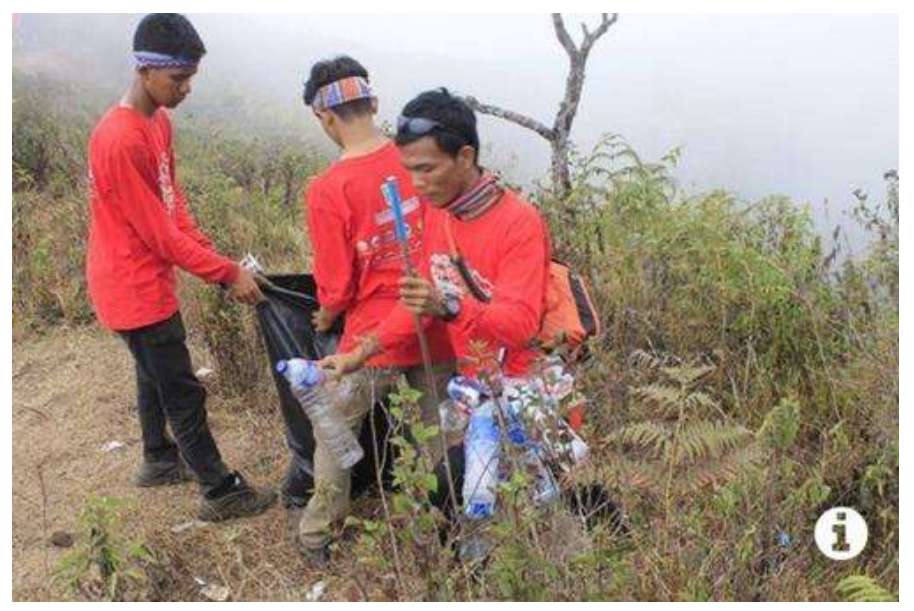

In paragraphs, $12^{\text {th }}$ and $13^{\text {th }}$, The Chief Executive of Sapu Jagad 2017, Gerry Patra Prawira predict that at least five tons of garbage will be collected by many participants. Besides, to clean up mountain trash, Sapu Jagad 2017 


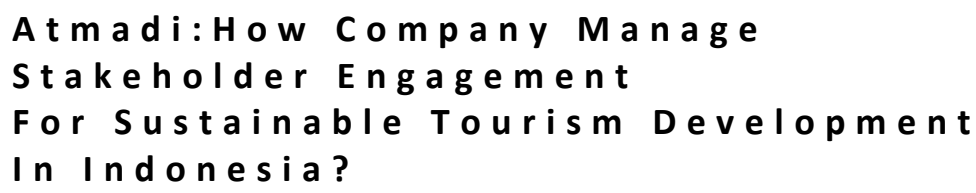

campaign also gave education for mountain climbers about how important is the bad impact of waste on the balance of the ecosystem.

On 14th paragraph shows that Trashbag Community gives a short message to the mountain climbers to bring your trash home because the mountain is one of our playground that must be kept clean and environmentally sustainable.

In the 15th paragraph, Gerry said that the participants came from Nature Lovers (Sispala), Nature Lovers Students (Mapala), Climbers to Nature Lovers Group (KPA) and community members. It means that the Trashbag Community can bring together various young people to work together to clean mountains.

On 16th paragraph shows that this campaign is not only to clean mountains but is actually an effort to educate and persuade mountain climbers to realize the importance of maintaining environmental cleanliness. In other words, environmental issues must be taken seriously because if not this could result in environmental damage and give a bad image for Indonesian tourism.

In paragraph 17, kompas.com explains that Aqua Group supported Sapu Jagad 2017 campaign. Arif Fatullah as Senior Manager of Sustainable Development Aqua Group said that the involvement of Aqua in that campaign was part of the company's responsibility to be responsible for its plastic waste. From a corporate communication perspective, that campaign is also a good event for public relations activities because Aqua's employees who participated in that campaign could interact with many kinds of young people while removing more plastic from the Indonesian mountains area.

Then, the fourth photo as seen in Figure 8 indicates a large pile of black and big garbage plastic bags with the words " Mountain is not a Trash Can “. Tuberculosis seems to have prepared carefully all the needs for clean equipment clean trash in the mountains as a natural tourist area that attracts many travelers. 
Figure 7

Piles of trash from the mountain of Trashbag Community members' hard work

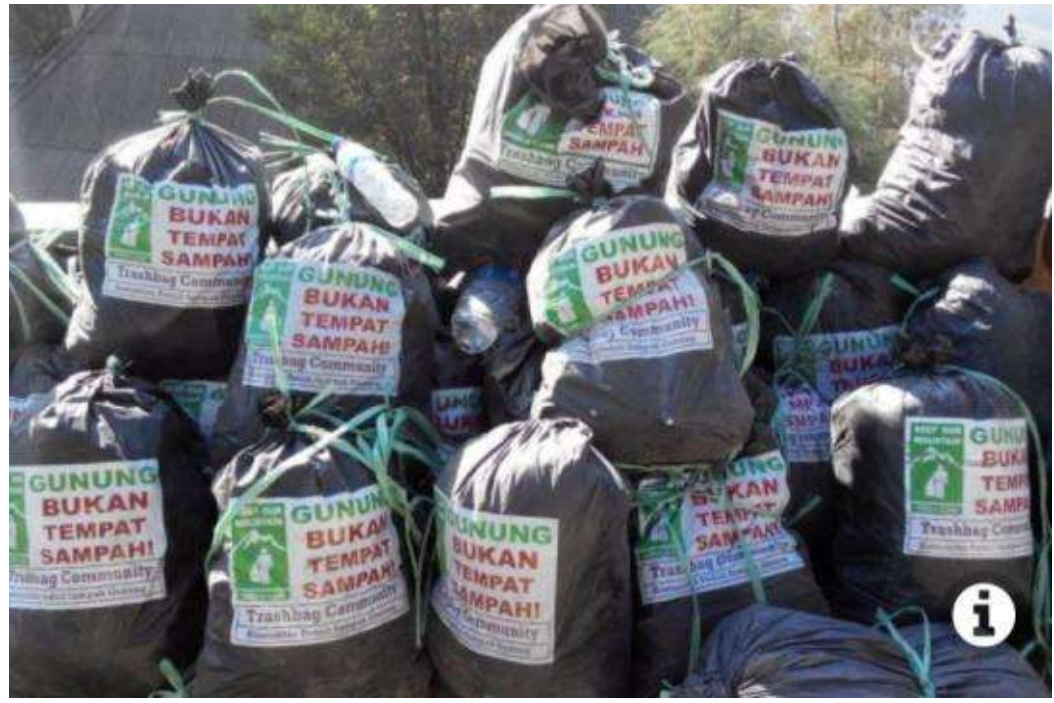

In the $18^{\text {th }}$ paragraph, Arif said that plastic bottles can be useful if managed properly. Unfortunately, there are still many people throw litter. Actually, Aqua has just launched its \#BijakBerplastik (Mindful Plastic Use) public campaign. This campaign is a movement that focuses on three core aspects that are critical to tackling plastic waste issues in Indonesia, namely: product innovation, consumer education and the development of waste-collection infrastructure. The movement calls for collaboration among stakeholders of all backgrounds in innovating and scaling solutions to plastic issues in Indonesia.

The last two paragraphs (19th and 20th paragraph) describes information about 17 locations of the mountains that were targeted by Sapu Jagad 2017, namely: (1). Talang mountain (West Sumatra), (2).Kerinci Seblat National Park (Jambi), (3). Pulosari Mountain (Banten), (4). National Park of Halimun Salak Mountain (West Java), (5). National Park of Ciremai Mountain (West Java), (6). Curry Mountain (West Java), (7). Slamet Mountain (Central Java), (8). Sindoro Mountain(Central Java), (9). National Park of Merbabu Mountain (Central Java), (10). Lawu Mountain (Central Java), (11). Penanggungan Mountain (East Java), (12). Welirang Mountain (East Java), (13). Batur Mountain (Bali), (14). National Park of Rinjani Mountain (West Nusa Tenggara), (15). Serang Mountain (West Kalimantan), (16). Nokilalaki Mountain, National Park Lorelindu (Central Sulawesi), (17). Bawakaraeng (South Sulawesi). 


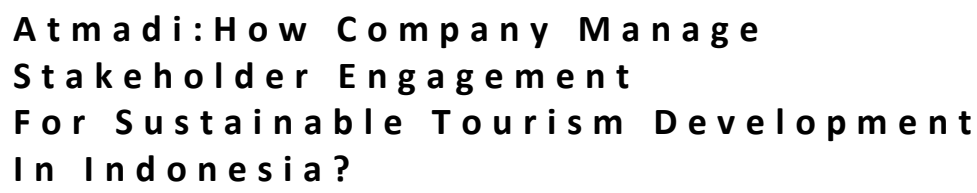

The following is information from wikipedia.org about some popular tourist destinations on mountain area that were targeted by Sapu Jagad 2017, such as :

Talang Mountain is an active stratovolcano in Solok regency, West Sumatra. Talang has two crater lakes on its flanks, the largest of which is 1 x $2 \mathrm{~km}$ wide and is called Lake Talang. Mount Talang has had eight confirmed eruptions between 1833 and 1968. Mount Talang is 2,572 meters above sea level and has many exotic and rare species, one of which is a tropical pitcher plant. Nepenthes inermis is probably the rarest variety of tropical pitcher plants. This plant lures insects and digests them to stay alive.

Mount Kerinci is a volcano in Sumatra island that is surrounded by the lush forest of Kerinci Seblat National Park as the Indonesia's Tropical Rainforest Heritage of Sumatra that was declared by United Nations Educational, Scientific and Cultural Organization (UNESCO) to be World Heritage Sites in 2004 and was made a heritage site in 2011 as it has potential for the conservation of the diverse flora and fauna of Sumatra. The park is also home to many endangered species. On September 2017, The Kerinci Seblat National Park Management Agency has approved the opening of a new trekking path to Mount Kerinci. Mountain climbers can soon reach the highest volcano in Indonesia via South Solok, West Sumatra. Kerinci mountain is at 3,805 meters above sea level.

Pulosari Mountain is a volcano with elevation 1,346 meters at the western end of Java or in Pasireurih, Cipeucang, Pandeglang regency, Banten. Although no historical eruptions have been recorded, there are active solfataras on its 300 meters deep caldera wall.

In the area of West Java, there is National Park of Halimun Salak Mountain. Established in 1992, the park comprises two mountains, Mount Salak and Mount Halimun that is located near Mount Gede Pangrango National Park. Mount Halimun Salak National Park is a $400 \mathrm{~km} 2$ conservation area that should be accessed from Sukabumi. For safety precautions, climbing the mountains are currently strictly prohibited, however, the canopy trail is one of the most anticipated experience for walking through a 125-meter canopy bridge 30 meters above the grounds, supported by 7 large trees. Jungle trekking is also a main event 
for those who appreciate nature's bliss. Cimacan waterfall is also a great place to hang around.

In Central Java, Slamet Mountain is an active stratovolcano in Purbalingga regency and is located on the border of Brebes, Banyumas and Pemalang Tegal regency. Slamet Mountain with an altitude of 3,428 meters above sea level is the highest mountain in Central Java and the second highest in Java island after Mount Semeru. It has a cluster of around three dozen cinder cones on the lower southeast-northeast flanks and a single cinder cone on the western flank. The volcano is composed of two overlapping edifices. At the foot of this mountain, there is the Baturaden tourist area. Slamet is one of Java's more active volcanos and there is almost always lots of gas around at the crater.

National Park of Merbabu Mountain is located in Central Java, near the city of Yogyakarta that features beautiful wildflowers and is only recommended for very experienced adventurers. The trail is primarily used for hiking and bird watching and is best used from March until October. Mount Merbabu has five official climbing routes, namely Wekas Route in Kenalan Village, Pakis District, Magelang Regency, the Selo Routine Tarubatang Village, Selo District, Boyolali, Cunthel Route in Kopeng Village, Thekelan Route in Batur Village, Getasan District, Semarang Regency, and Suwanting Route in Banyuroto Village, Sawangan District.

Mount Penanggunganis located between two regions in East Java in Mojokerto and Pasuruan. Penanggungan is one of the favorite destinations of hikers in East Java besides Mount Bromo and Mount Semeru. This mountain is suitable for beginners starting trekking. Though it is not too high, it can present a trekking sensation encouraging adrenaline. Mount Penanggungan has a mountain having important values for Hinduists in Java. This mountain is not a volcano so that trekking is very safe and secure. From the top peak of Mount Penanggungan, hikers can see Mount Arjuna and Welirang located in one cluster of Mount Penanggungan.

Welirang Mountain is a stratovolcano in the province of East Java. Mount Welirang is a Javanese word of sulfur. Welirang also said as a twin mountain with Arjuno volcano that has become the destination of the climbing tour in Tretes, Malang area. Welirang and Arjuno volcano set in the ancient Mojopahit heartland and is dotted with temples, graves and other historical sites that are still visited by 


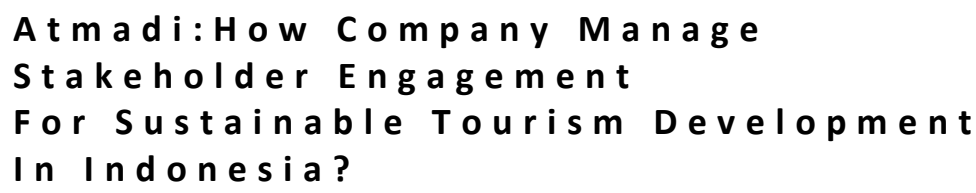

local folk today. From the highest point of 3,156 meters, we can enjoy marvelous views over the region. Welirang mountain is possible climbed in all seasons. Some visitors normally choose Welirang climbing whenever the Semeru volcano hiking package has closed.

Mount Batur as seen in Figure 10. is an active volcano located at the center of two concentric calderas northwest of Mount Agung in Kintamani, Bali. The Kintamani era consists of three main villages, namely Penelokan, Batur, and Kintamani. Mount Batur is very popular for trekking and climbing. Everyone can observe the sunrise from the ridges of this Bali volcano on early morning treks. From up high, we can enjoy beautiful Batur caldera to the northwest. Lake Batur is on the southeastern side of the volcano with $16 \mathrm{~km}$ wide and is a popular fishing spot. Lake Batur is the main source of irrigation water for most of Bali. Batur's village of Toya Bungkah has lakeside hot springs, known for its curative mineral water. The water temperature at the Toya Bungkah hot spring can reach up to $450 \mathrm{C}$. It is a popular choice among trekkers to spend the night before hiking up Mount Batur in time to watch the sunrise. Be sure to check its volcanic activity alert levels before planning a trek.

Figure 8

Some tourists enjoyed the beauty of Mount Batur at Kintamani, Bali

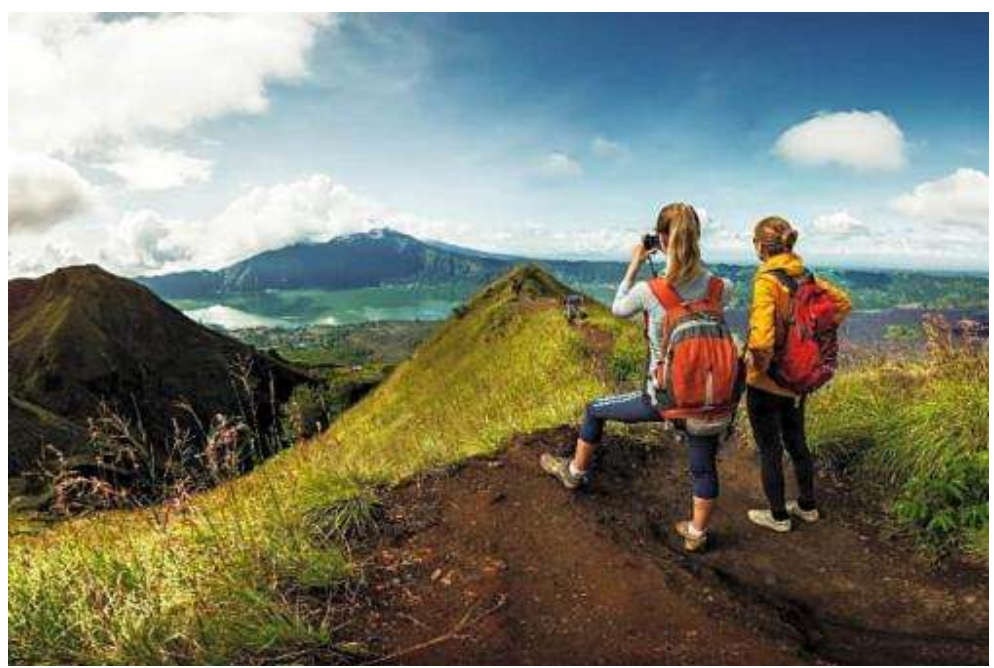

(Source : https://thetripguru.com/tour/a-guide-to-trekking-mt-batur) 
At 3,726 m, Rinjani Mountain is the second-highest volcano in Indonesia and located in Lombok, West Nusa Tenggara. Rinjani erupted three further times on 23 May 2010 with activity continuing until 24 May 2010. The lower and midlevels of the mountain are quite heavily forested. The views of the crater lake are quite breath-taking from the caldera rim. From the absolute peak, we can see Bali to the west and Sumbawa to the east. In 2008, the Indonesian government proposed to UNESCO that Mount Rinjani be one of the world's official geo-parks. If this was approved by UNESCO, Mount Rinjani would become the first such geological park in Indonesia.

Nokilalaki Mountain with an elevation of 2,357 meters is located in Palolo, Sigi regency, Sulawesi. This mount is a very attractive-looking forest peak in Lore LinduNational Parkland has the most straightforward trail in Central Sulawesi. This national park has at least five species of squirrel, and approximately there are 55 species of bats inhabit this national park. Lore Lindu National Park covers 217,991 hectares of Central Sulawesi. There were many Sulawesi endemic faunas which have been found in this park.

In South Sulawesi, there is Bawakaraeng Mountain at 2,883 meters above sea level that is located in Gowa regency. In the local dialect, Bawakaraeng translates as " Mouth of God ", reflecting the belief by many of the surrounding villages that the mountain is sacred. Many local pilgrims make the climb to summit in the months leading up to Idhul Adha. The trail is in excellent condition and can be easily followed without the help of a guide. Although the Bawakaraeng trek is relatively straightforward, everybody does need to be well prepared because of wind and misty clouds.

The narrative analysis indicates that Aqua company did stakeholder engagements by being a supporter of the Sapu Jagad 2017 campaign with Trashbag Community and The Ministry of Environment and Forestry. Moreover, Aqua also involved 111 Aqua employees in eight mountains participating and working together with the Trashbag Community to clean up the trash on some mountains. Plastic bottle waste brought to Mount Salak and Mount Batur will be sent to Trash Bank and Recycling Business Unit (RBU) managed by Aqua Group. Many of mountains that being targeted by Sapu Jagad 2017 campaign are natural tourist destinations that are liked by many tourist from domestic and international, such as : National Park of Rinjani Mountain on West Nusa Tenggara, National 


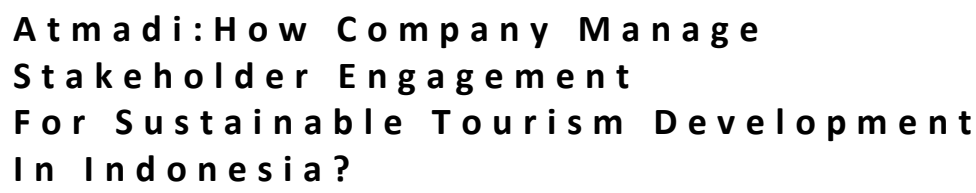

Park of Halimun Salak Mountain on West Java, Kerinci Seblat National Park on Jambi, and Batur Mountain on Bali. By participating in this campaign means that Aqua has participated in sustainable tourism development activities for the advancement of the world of tourism in Indonesia.

Gayatri Ahmadi said that Sapu Jagad 2017 campaign news review have been published by several digital media, such as kompas.com, media indonesia.com, the Jakarta post.com, tempo.com., suara.com., mix.co.id., and detik.com. and the impact of these publications can form a positive image for Aqua and others. Based on public relations perspective, Aqua company already made good media relations with some journalist from Kompas, Media Indonesia, Jakarta Post, Tempo, Suara, Mix and detik that all of them published positive tone so that many audiences realized and knew that Aqua was a responsible company for sustainable tourism. Consequently, Aqua Public Relations can make a good public opinion in society. Every company is concerned about its public opinion for a good reputation and its success in general (Atmadi, 2019).

The result of this research argues Michael Risteski et al who said that for the tourist destinations to survive well, one way of achieving that target could be the orientation to improve the implementation of environmental sustainability. For tourism and tourist destinations, we must think smartly not only one company is concerned, but also a big number of stakeholder engagements (Risteski, Michael, Kocevski Jordan, 2012).

This finding confirms Maryam Ziaabadiet al. who said that the relationship between tourism and the environmental health should be arranged in sustainable development so that we can have stable environment condition for long period and we should not let tourism damage natural resources and job creation so badly in future (Ziaabadi et al. 2017).

This finding also confirms Esben Rahbek Gjerdrum Pedersen et al. who explained that stakeholder thinking has been gradually more important on the corporate agenda. However, there is still a need to understand better how companies can apply stakeholder thinking for the benefit of both business and society(Pedersen. et Al, 2013). Finally, this finding confirms James Noland and Robert Phillips who explained that stakeholder engagement has received very 
serious attention in recent years because stakeholders make up the firms and the relationship networks to which these stakeholders belong make up the communities and markets within the firms do business (Noland and Robert, 2010).

\section{CONCLUSION}

The topic of sustainable tourism development has received greater attention in recent years. During the threat of plastic pollution that disrupts the environment at the sea and mountains area, some digital media already published about the efforts of companies, government, and communities for reducing plastic waste in mountains area as tourist destinations. As a result of narrative analyzing, kompas.com explains that Aqua company managed stakeholder engagement by doing corporate social responsibility program as a supporter of the Sapu Jagad 2017 campaign with Trashbag Community, The Ministry of Environment and Forestry, and some journalists from several mass media. Stakeholder engagement is the most important ingredient for a successful public relations program.

By managing stakeholder engagement successfully, the company can also perform its corporate social responsibility to society as a part of the public relations strategy. Corporate social responsibility is originally conceived as a way for the company to have a positive impact on its stakeholders. Corporate social responsibility can make for a great media story that sets you apart from competitors. Consequently, from good publications on digital media, Aqua can gain a good image and good reputation as a producer of bottled water with plastic bottles that care about plastic bottle's trash that is manufactured. The most important thing is that the company can support sustainable tourism development in mountains and national parks area as tourist destinations for local travelers and international travelers, such as National Park of Rinjani Mountain on West Nusa Tenggara and National Park of Halimun Salak Mountain on West Java.

\section{REFERENCES}

Al, P. et. (2013). Stakeholder Thinking in Sustainability Management : The Case of Novozymes. Social Responsibility, 9(4).

Al, Z. et. (2017). How to Use Composite Indikator and Linear Programming Model for Determine Sustainable Tourism. Journal Environmental Health 


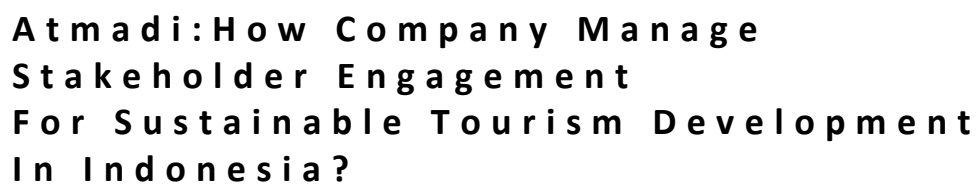

Science and Engineering, 15(9).

Atmadi, G. (2019). How Company Manage Stakeholder Engagement for Reducing Plastic Waste in Indonesia? in Communication, Culture and Media Studies. Yogyakarta: University of Islam Indonesia.

Bourne, L. (2009). Stakeholder Relationship Management. England: Gower Publishing Ltd.

Brugha, R. and V. (2019). Health Policy and Planning. Brugha, R. and Varvasovszky, 15(3), 239-246.

Butarbutar, R. and S. (2013). Enviromental Effect of Ecotourism in Indonesia. Indonesia Tourism and Development Studies, 1(3).

Butler, R. A. (2016). The Top 10 Most Biodiverse Countries. Diambil dari https://news.mongabay.com

Cornelissen, J. (2009). Corporate Communication A Guide to Theory and Practice. London: Sage Publication Ltd.

Eriyanto. (2013). Analisis Naratif, Dasar-Dasar Dan Penerapannya Dalam Analisis Teks Berita Media. Jakarta: Prenadamedia Group.

Kahfi, K. (2019). Government Drafts Industrial Change Road Map To Reduce Plastic Waste. In Thejakartapost.Com.

Lai, C.S., C. J. Chiu, C. F. Yang, and D. C. P. (2010). The Effects of Corporate Social Responsibility on Brand Performance : The Mediating Effect of Industrial Brand Equity and Corporate Reputation. Business Ethics, 95(3), 457-469.

McWilliams, A., D. S. Siegel, and P. W. (2006). Corporate Social Responsibilities : Strategic Implications. Management Studies, 43(1), 1-18.

Miles, A. L. F. and S. (2006). Stakeholders Theory and Practice. Oxford: Oxford University Press.

Polonsky, M. J. and R. S. (2001). Linking Sponsorship and Cause Related Marketing : Complementary and Conflicts. European Journal of Marketing, $35,1362-1389$.

Programme., U. N. E. (2008). Sustainable Tourism Development in UNESCO Designated Sites in South-Eastern Europe, Ecological Tourism in Europe (ETE). VENICE: UNESCO OFFICE.

Risteski, Michael, Kocevski Jordan, and K. A. (2012). Spatial Planning and 
Sustainable Tourism as Basis for Developing Competitive Tourist Destinations. Journal Procedia - Social and Behavioral Sciences, 44, 375386.

Robert, J. N. and P. (2010). Stakeholder Engagement, Discourse Ethics and Strategic Management. International Journal of Management Reviews, 12(01).

Wolfe, R. . and D. . P. . (2002). How Tight Are The Ties That Bind Stakeholder Groups? Journal Organization Science, 13(1), 64-80.

Yazdi, S. K. (2012). Sustainable Tourism. Social Science, 1(1).

Zaman, M. A. S. M. A. S. dan K. (2016). "Tourism in Austria : Biodiversity, Environmental Sustainability, and Growth Issues." Environmental Science and Pollution Research, 23(23), 24178-24194. 